Article

\title{
The Art of Democracy-Art as a Tool for Developing Democratic Citizenship and Stimulating Public Debate: A Rortyan-Deweyan Account
}

\section{Michael I. Raeber}

Department of Humanities, Social and Political Sciences, ETH Zurich, Haldeneggsteig 4, 8092 Zurich, Switzerland; E-Mail: michael.raeber@phil.gess.ethz.ch; Tel.: +41-44-633-1561;

Fax: +41-44-632-1561

Received: 27 March 2013; in revised form: 19 April 2013 / Accepted: 25 April 2013 /

Published: 6 May 2013

\begin{abstract}
Richard Rorty holds that the novel is the characteristic genre of democracy, because it helps people to develop and to stabilize two crucial capabilities the ideal inhabitants of democratic societies should possess: a keen sense for anti-foundationalism and a disposition for solidarity. He believes that novels help develop these capabilities by educating our capacity for criticism and our capacity for attentive-empathetic perception. This article argues in favor of this Rortyan idea, showing how anti-foundationalism and solidarity can be seen as important instances of what I will call 'dispositions for democratic citizenship' and that art (and not only novels) and its reception, are valuable tools for advancing these dispositions. However, as the Rortyan public-private dichotomy assigns art's function of criticism only to the private sphere, Rorty ignores its potential for stimulating democratic public deliberation and he misses the fact that art's functions of criticism and of attentive-empathetic perception partially depend on each other if they are effectively to lead to increased solidarity and change social realities. Thus this article argues - taking these objections into account-to slightly modify, but nevertheless value Rorty's idea that art and its reception are crucial resources for democratic citizenship and for the process of democratic deliberation.
\end{abstract}

Keywords: aesthetics and philosophy of art; anti-foundationalism; democracy; democratic citizenship; Dewey; political criticism; pragmatism and neo-pragmatism; public debate; Rorty 


\section{Introduction}

Richard Rorty argues that the novel is "most closely associated with the struggle for freedom and equality" and thus is the primary instrument of moral reflection in a democratic society [1]. He holds, that by educating our sentiments, novels can help to fashion a democratic moral society of individuals aware of the suffering of others and likely to be willing to integrate those different from us into what 'we' are. Rorty emphasizes that democracy is necessarily linked to the plurality and contingency of human perspectives, and as great novels inherently display this pluralism and contingency, they are for him the primary instruments for influencing — what one could call—the 'political psychology' of individuals so that they might be educated to act democratically, that is for Rorty to aspire towards freedom, equality and a form of loyalty to other human beings.

In order to understand why Rorty believes that novels and narratives in general are the primary instruments for building up an individual's capacities and motivation to think and act in accordance to the ideals of democracy, we have to take into account his meta-philosophical conviction. This is that shifting the focus of political theory away from a preoccupation with aloof attempts to obtain a set of universal truths about politics towards the idea of redescription as political intervention makes political reflection much more effective in terms of actually shaping or reinforcing the individual's preferences for equality, freedom and other ideals and institutions that are relevant for democracies. Redescription for Rorty is transformational rather than representational, words and knowledge for Rorty should be seen as instruments of change rather than as accurate representations of reality. With the idea of redescription as political theory, Rorty demands that philosophical-political reflection should inspire us to abandon our attitude of passive spectatorship in favor of embracing direct engagement, in short: philosophical political reflection should be practiced as political intervention. And that is for Rorty best done in crafted novels and imaginative visions designed not to illuminate truth but to deploy perspectives designed to inspire change. Rorty is convinced that redescriptions in the shape of novels produce amendment by assisting us to "alter our self-image" [2]. He sees them as sources for an intellectual reflection that deal with the details, particulars and archetypal characters of individuals and situations that are formative for individual dispositions or social structures. However, not only are novels, films and other artistic creations informative sources for intellectual reflection, moreover they can, at least this is Rorty's hope, take formative action in individual political passions and preferences.

This article will argue in favor of the Rortyan idea that anti-foundationalism and solidarity are important instances of what I will call 'dispositions for democratic citizenship' and that not only novels but art in general and its reception are valuable tools for supporting those dispositions by means of criticism and education of perception. I show first how to make sense of his claim that those 'virtues' are crucial for democratic citizenship. Second I outline what Rorty believes are the connections between those dispositions and art and its reception. I then argue that, as the Rortyan public-private dichotomy assigns art's function of criticism only to the private sphere, Rorty ignores its potential for stimulating democratic public deliberation and that he misses the fact that art's functions of criticism and of aesthetic-moral perception partially depend on each other if they are effectively to lead to increasing solidarity and changing social realities. I put forward elements of John Dewey's concept of art that removes deficiencies left by Rorty. Thus, finally, I suggest-taking these objections into 
account - to slightly modify, but nevertheless value Rorty's idea that art and its reception are crucial resources for democratic citizenship and for the process of democratic deliberation.

\section{Two Dispositions of the Ideal-Typical Democratic Citizen: Anti-Foundationalism and Solidarity}

The inhabitants of Rortyan liberal democratic utopia, the “liberal ironists”, exemplify Rorty’s ideal for participants of western democracy. Liberal ironists stand firm in their believed values while at the same time accepting the contingency of these very values. The awareness of contingency even designates their self-perceptions; ironists constitute their identities through constant self-relativization and self-re-creation and understand themselves as antithetical to the 'metaphysician' who is tempted to regard a given final vocabulary, which for Rorty everybody inevitably has, as fixed, natural, and not amenable to contingency. All vocabularies (including their own) are submitted to the ironists' criticisms implying that they dissociate from existing vocabularies by creating new words, meanings and stories. In this manner personal identity becomes constituted as the "center of narrative gravity" [3] - a narrating consideration of one's life that is constantly revised. By renouncing any foundational argumentation or legitimation, the ironists release their creative powers in order to create their own contingencies. 'Liberal Ironists', then, are 'anti-foundationalists'.

The term 'anti-foundationalism' is vague and ambiguous. It is defined primarily ex negativo, denying any foundationalist demand that would give answers to questions of truth and correspondence vis-à-vis some noncontextual or unhistorical realities or values. Foundationalist claims imply furthermore that ideas ought to exist which we can know with absolute certainty. The reason for that demand lies in a fear of a skeptic-relativistic disorientation. In a quote from Frege's The Foundations of Arithmetic (Grundlagen der Arithmetik) this fear is explicitly addressed: "If everything were in continual flux, and nothing maintained itself fixed for a1l time, there would no longer be any possibility of getting to know anything about the world and everything would be plunged in confusion” [4]. That fear of Frege is opposed by the fear of Rorty that any possible foundational claim is in danger of being authoritarian and oppressive, insofar as foundational claims get their force (to speak with Peirce) either from God, God-like humans or unconditional a-priori principles. With regard to Rorty these three features of anti-foundationalism (anti-realism; fallibilism; fear from coercion) can be expressed with his epistemological claims of "anti-representationalism”, “contingency” and the ethical claim of "humanism". With regard to the latter, Rorty called his position a "militant anti-authoritarianism" [5]. It's rather strange that he attaches this fear only to ahistorical justifications, as it is easy to see how historicized justifications that are based on principles and practices of a certain ethnos are, just the same, susceptible to be authoritarian. However, what Rorty-more positively expressed-means is what Bernstein characterizes as Rorty’s “deep humanism” [6]. Humanism here means that anti-foundationalism should primarily be understood as a humanistic mindset, namely that there is nothing that we can rely on but ourselves and our fellow human beings. Of course, our fellow human beings could be an authoritarian source as well. However, humans at least have the ability and most likely the duty to legitimate their actions and dispositions, rocks in turn do not have such skills and duties, as they do not act and do not have any dispositions. 
One could assume that ironist and anti-foundationalist citizens are not approximately identical, as for Rorty an ironist is someone who "has radical and continuing doubts about the final vocabulary she currently uses, because she has been impressed by other vocabularies" and because ironists would be intellectuals while non-intellectuals would not be ironists [7]. "The latter would, however, be commonsensically nominalist and historicist” ([7], p. 87). The crucial difference between mere anti-foundational nominalist-historicist members of a Rortyan society and ironists seems to be that ironists, in addition to being nominalist and historicist, do maintain radical and unsolvable doubts about their own and other vocabularies. But as Michael Bacon points out, the difference between radical and commonsensical doubt is not that clear cut [8]. The difference between the radically doubting intellectual and the merely commonsensically doubting non-intellectual is reducible to a gradual difference in a tendency to doubt. While ironists might cultivate radical and unsolvable doubts towards all (their own and other) vocabularies and beliefs, they cannot question all coevally and with the same intensity. Ever since Peirce, the conviction that some beliefs are firmer than others or unlikely to change (and, in Rorty's terms, are near to the core of "narrative gravity”) has been counted among the most basic principles of pragmatism. As Rorty says: "We call certain people 'intellectuals' because they have the brains and guts to keep their self-image flexible. ... The difference between intellectuals and the masses is the difference between those who can remember and use different vocabularies at the same time, and those who can remember only one” [9]. As a result, the controversial notion of ironism can be simply substituted with the modest concept of antifoundationalism. Rorty concedes that "ironism ... means something close to antifoundationalism. ... It is just a sort of attitude, the way you feel about yourself, a form of life” ([9], p. 40). Of course, to have a decidedly anti-foundationalist mindset is a state that is hard to reach, because it seems paradoxical to be nothing more than a web of beliefs and to act upon them while at the same time being ready to stand back from exactly those beliefs by calling them into question.

Yet, Rorty was ambiguous with what he really meant by "ironism”. There are passages in his writings that are vulnerable to attacks from critics of his concept of ironism, especially where he insists on quarantining ironism in the public sphere by privatizing it. If we think of ironists as having a light-hearted, laissez-faire and cynical attitude towards other people's problems and desires and being merely concerned with the private task of pursuing their own selfish desires, we can understand why the Rortyan ironists are said to be incapable of participation as citizens or that if they would participate, they would do it only and throughout cynically. However, Neil Gascoigne convincingly demonstrates that such an interpretation of what Rorty meant with ironism would be a misunderstanding [10]. He points out that while the difference between intellectuals and non-intellectuals in their tendency to doubt is a gradual one, it nevertheless is significant for two reasons. Firstly, intellectuals who radically doubt any final vocabulary show a heightened alertness to 'moral inventions'. In other words, they are open to the fact that in regard to morality something better might arise. Secondly, in this connection, for Rorty, ironism is a normative mode of self-understanding for intellectuals. Ironists are existentially characterized by their awareness of both the fact that redescriptions often do humiliate other people and that their project of self-creation is not a creation $e x$ nihil but is only parasitic upon normal language. Ironism, then, is an instance of what Rorty meant with humanism — that there is nothing that we can rely on but ourselves and our fellow human beings. 
Brint/Weaver/Garmon argue that there lies no political theory in anti-foundationalism, from which no Leftist or Rightist politics could be derived from. They hold that “... no particular political position, practice, principle, doctrine, set of beliefs, or program follows from taking an anti-foundationalist stance”. And they go on arguing that “... anti-foundationalism is just as available to fascists as to Fabians, as open to purveyors of cruelty as to expanders of liberty” [11]. They are certainly right in pointing out that no particular political orientation follows from anti-foundationalism and that it neither rejects nor endorses any particular politics. But, in opposition to fascism, Fabianism and the like, anti-foundationalism and democracy both in their ways are related to the idea that all knowledge, values and all political decisions are hypothetical and fleeting and that they may be contested and replaced. Anti-foundationalism's epistemological insight that there are no dependable final foundations of knowledge contains the crucial political lesson that there is no ensured final way of obtaining good politics, laws or institutions. As a consequence the democratic citizenry, consisting of a plurality of different individuals and interest groups, should be empowered to vote bad rulers out of office and expose bad policies. The political process of deliberation and voting in democracies can be compared to other experimental activities in which contestation and exploration leads to the amendment of deficient systems of representation. Consequently, anti-foundationalism does have a meaning for political theory-it seems to be incompatible with anti-democratic practices and is only compatible with democratic (political) settings. In democracies, political action is of experimental and provisional nature. Democracy itself, as Dewey highlighted, is unfinished, and ideal rather than a fact, "namely, the tendency and movement of some thing which exists carried to its final limit, viewed as completed, perfected. Since things do not attain such fulfillment but are in actuality distracted and interfered with, democracy in this sense is not a fact and never will be” [12]. Democracy, to that effect, is an open-ended process without absolute authorities or outright certainties. Logically this means that anti-foundationalism is a necessary condition of democracy. This is not to deny that democracies do have solid and enduring fundaments - institutions, regulations, processes, patterns of action or communication-and that democratic decisions do have a strong path dependency making it difficult to reverse or modify them. Yet from a historical point of view one can claim that foundationalism often results in anti-democratic practices and governments. Consider for instance the fact that a non-democratic regime like Nazi-Germany grounded its actions and convictions on foundational ideals like 'nation' and 'race'. Fascists would never adopt an anti-foundationalist attitude, because they could never give up the belief that there exist some absolute and certain ideas, ideals and practices.

What follows is that, as Rortyan ironists are 'refined' anti-foundationalists, being an ironist in that sense (and that equals to thinking and acting in accordance with the idea of anti-foundationalism) is a necessary part of being a democratic citizen. Being an ironist (having an anti-foundationalist attitude) then can be compared to patterns of political socialization that are required for a democratic political culture to emerge or to be maintained, in which conflictual tensions among competing ways of life, identities and world views are tolerated and resolved without violence [13].

A strong sense for "solidarity" is the second important constituent of Rorty's ideal-typical democratic citizen. The ideal democratic citizen for Rorty would grasp at increasing solidarity. That solidarity and democracy de facto go hand in hand is not hard to see as solidarity in modern liberal democracies, that is, in social democratic welfare states, is institutionalized in procedural and institutional settings. The individualistic normative notion of solidarity as compassion, sympathy or 
understanding on part of the civil society manifests itself in democratic institutions and procedures that generally allow for minority groups to be heard and to influence politics. That is why for Rorty democracy is primarily a tool for those who are suffering. And being a tool for them, democracy leads to the reduction of their suffering: "In a fully democratic society, unnecessary suffering would not exist” ([9], p. 82). What “unnecessary suffering” here means remains under-determined; Rorty only refers to "the cruelty of whites against blacks, for example, or the suffering of gays" as examples of unnecessary suffering. If there exists unnecessary suffering, there must, logically, also exist necessary suffering or at least tolerable suffering. However, he does not give any examples of that. Besides, considering the nagging problem of the tyranny of the majority that has been raised by many critics of democracy, a direct link between democracy and solidarity is not obvious. If we understand democracy primarily or exclusively as a method to limit governmental power by voting once in a while, democracy will not have that much in common with solidarity. Be that it is not my aim here to contribute anything to the problem of how to establish and ensure minority rights, to the problem of how to build majorities or to the problem of foras or institutionalized channels where minorities can make their voices heard, I will ignore this problem in this instance. In any case, Rorty was convinced that democracy should be a tool for those who are suffering, although he was unclear about how to achieve this goal.

Increasing solidarity for Rorty means that our sensitivity is enhanced with regard to the particularities of the suffering and humiliation of others and as a result it leads to a reduction of cruelty. He defines solidarity as,

... accepting reciprocal responsibility to other members of the group for the sake of common purpose. In that sense the Communist Party of the Soviet Union had solidarity, the Nazis had solidarity, Mao's cultural revolutionaries had solidarity. The bad guys can have solidarity too. Solidarity is morally neutral, so to speak ([9], p. 61).

And furthermore he describes it as,

... a sense of other people and ourselves being 'we'-we feel that what affects them affects us because we, to some extent, identify with them. I was trying to describe social progress in a way borrowed from Wilfred Sellars: the expansion of 'we' consciousness, that is, the ability to take in more and more people of the sort fashionably called 'marginal' and think of them as one of us, included in us ([9], p. 32).

Rorty uses "solidarity" in those passages in two different ways. First, solidarity for Rorty is a neutral social tool that has the function of creating a common identity, a 'we' (we Americans, we Ironists, we Aryans, ...). Second, as being a neutral social tool it has to be put into service for the right end, and that end is for Rorty reducing cruelty. On an individualistic level Rorty's notion of solidarity can be translated as compassion, sympathy or understanding towards other people. It is his hope that when we get affected by other people's needs and sufferings and see them as our needs and sufferings that we feel bound to act in a way that reduces their sufferings and satisfies their needs. On the level of community solidarity for Rorty means, if I understand him right, the integration of other people into a liberal democratic ethnos. This is to say that Rorty's concept of solidarity is more than just a morally neutral social tool, it is a normative concept as it includes an enlargement of our 'we', of our identity. Enlarging our 'we' can mean both including people who once were 'other' people into a prefixed 'we' 
or redefining what 'we' is by giving new and extended meaning to it. And loyalty to a common 'we' can be an important engine of moral solidarity for Rorty. However, being loyal to a common 'we' in Rorty's sense has two opposed and conflicting meanings. For one thing it means loyalty to real existing liberal democratic ethnoi (in Rorty's case primarily the United States). For the other it means loyalty to the unattained but attainable ideals of liberal democracy, the liberal utopia. In other words, there is a tension between loyalty to the factual 'we' of identity and loyalty to the normative 'we' of a Sellersian 'we-consciousness'.

To sum up, Rorty's ideal-typical democratic citizens are men and women who have internalized the habits of the mind and the habits of the heart-the dispositions for anti-foundationalism and solidarity - that are essential for the conduct of democratic self-government. As I have mentioned before, Rorty does believe that narratives in general and novels in particular are eligible tools to promote those two dispositions and that because of that novels thus should be called 'the characteristic genre of democracy'. In the next 2 sections I will explain what he exactly means by that and in doing so I will both point out some internal difficulties and suggest taking into account art's potential for aesthetic-moral perception and social criticism in general.

\section{Novel's Political Function of Educating our Capacity for Aesthetic-Moral Perception}

We can identify in Rorty's thought two conceptions of the role of novels in democratic societies [14]. On the one hand, novels for Rorty serve to install and stabilize common vocabularies or hopes and educate to a morality of solidarity with the aim of reducing cruelty. On the other they provide a means of criticism and self-creation.

Let me first consider the moral-educating role Rorty assigns to novels. His idea of sentimental education through novels is based on a replacement of reason by imagination as the crucial human capability and emphasizes the role of sentiments in moral judgment. Sentimental novels, stories or pictures that display the suffering and pain of others and directly appeal to people's sentiments, could lead for Rorty to a kind of moral progress toward a more humane social world. What Rorty believes happens when we are confronted with the suffering of others is that we enlarge our sense of identity, our ability to imaginatively identify with those suffering and as a result maybe we tend to reduce cruelty. By manipulating sentiments, for Rorty literature is best suited to the task of making us more sensitive to suffering. The function of imaginative identification with others includes two key features, both of them relevant in novels.

First, imaginative novels can help us to notice sites of the suffering that have been unnoticed by bringing them to our attention. Second, in order to identify with other people's fates we must know that they exist at all and for that we have to know details about their lives beforehand. Hence it is the task of novels to describe those fates in detail. These two integral aspects of novels can lead for Rorty to increasing our sensitivity to suffering and to the creation of fellow feeling.

In The Art of the Novel Milan Kundera-one of Rorty's references-describes the spirit of the novel in terms that remarkably resemble Rorty's idea of anti-foundationalism. Kundera opposes the novel as the nature of foundational philosophy, the world of multiple, conflicting perspectives to the world of one single truth and a dictated, unquestionable reality. The novel's function in that way is to contradict and subvert rather than to serve ideological certitudes. Kundera expresses this function with 
terms that resemble Rorty’s liberal utopia: “ambiguity”, “tolerance”, “diversity”, “fraternity”, and the importance of a protected private life [15]. Nevertheless, other than Kundera who sees the novel by definition as the "ironic art", Rorty does exclude the ironic (that is: anti-foundationalist) tools of subversion or contradiction from the public sphere; only for private matters, as a tool to become more autonomous, should irony be employed. One reason for that limitation is that irony for Rorty has the potential to humiliate and to be cruel ([7], pp. 87-89). We may concede that irony indeed has this potential, and if we understand it in the way Rorty does, namely as the primary tool for self-creation through discrimination from and negation of all other vocabulary, the very nature of anti-foundationalism would be to humiliate and to be cruel. Nonetheless, if the value of the novel for democracy is its capability to contradict any attempt to impose singular perspectives on diversity in Kundera's sense, why should this function of contradiction be of more value for the private realm than for the public sphere? Contradiction and subversion only make sense in connection with some sort of public discourse. Undermining any foundational certainty would be an essential goal in the public sphere of any truly democratic society, even for the price of slightly humiliating other people who hold those foundational claims.

Thus it is not so much anti-foundationalism which Rorty has in mind when he refers to novels as tools of moral-civic education that could eventually lead to an enhancement of solidarity, it is rather the idea that novels open up the moral imagination that would lead to a heightened awareness and sensitivity to the hardships of others. Richard Hart rightly described the Rortyean idea of the moral function of novels as "a line of evolution from opening the moral imagination, to enhanced sympathy-empathy, to cultivating proper moral sentiments, to expanded loyalty and the pursuit of greater justice” [16]. A novel like Nabokov's Lolita for Rorty somehow can change its readers by offering new insights into themselves and others, perhaps reinforcing and increasing their appreciation of and compassion to those in need. They have the potential for the reader to see and experience the world from the perspective of the strong characters in a story. Rorty is certainly right to hold that in delivering a "diversity of viewpoints, a plurality of descriptions of the same events" those novels thereby illustrate deep pluralism ([1], p. 74). Non-reductive, or in other words, polyphonic novels deliver different - in many cases conflicting — views on the same event, without privileging one of these views. In other words, they are anti-foundationalist. That is Kundera's point. But in addition to that, Rorty believes in the moral powers of novels to bring us to see other people's sufferings and needs.

The polyphonic quality of novels does not imply that on account of their particularity and attentiveness to the specifics of the lives of others, they will directly show people how to become better perceivers, and consequently alter them such that they act in more just and less cruel ways. Differently put, there is no linear line of evolution, as Rorty seems to have assumed, from reading polyphonic novels to the formation of moral sentiments and from there to a habit of acting upon the idea of solidarity.

Let me illustrate my point with one of Rorty's examples where we readers of polyphonic novels could sharpen our moral imagination. It is the scene in Nabokov's Lolita where Humbert Humbert visits the barber of Kasbeam. It goes like this:

In Kasbeam a very old barber gave me a very mediocre haircut: he babbled of a baseball-playing son of his, and, at every explodent, spat into my neck, and every now and then wiped his glasses on my sheet-wrap, or 
interrupted his tremulous scissor work to produce faded newspaper clippings, and so inattentive was I that it came as a shock to realize as he pointed to an easelled photograph among the ancient gray lotions, that the moustached young ball player had been dead for the last thirty years [17].

For Rorty, this short scene represents Humbert's lack of attentiveness to anything irrelevant to his own idiosyncrasies, a lack of curiosity for the details of other people's sufferings and their lives. This is a short scene, and the reader possibly will not notice the moral lesson that could be learned from this scene according to Rorty and Nabokov. The moral-educative effect of this scene for Rorty is not attained until the reader recognizes (with the help of Nabokov who in the afterword points out to the reader) that he or she was as inattentive to that scene, to that dead moustached son, as Humbert was inattentive. Thus the reader suddenly reveals to herself her accomplice in Humbert. This is the moral lesson that can be learned here for Rorty: "To notice what one is doing, and in particular to notice what people are saying. For it might turn out, it very often does turn out, that people are trying to tell you that they are suffering“ ([7], p. 164).

It is a quite elaborate interpretation of that particular scene from both Rorty and Nabokov. However, I doubt that the learned effect from reading this scene could be something of a moral lesson. It is just not the same sort of curiosity that is lacking by overlooking an important passage in a fictional text to not noticing the suffering of existing fellow human beings. In one case we may discover with irritation that we did not see at first sight what we see now, namely that we missed one important piece of the story we read or heard, similar to the scientist who finds it dreadful that he missed an important fact necessary to make his theory better or more complete. In other words, what was lacking in this case is that we were not intellectually attentive enough, not intellectually accurate enough. In the case of actually ignoring the suffering of someone that I could and should have noticed, my indifference might have far-reaching consequences. I might then discover not with an aloof irritation that I missed an important part of a story, but I might emotionally, affectively, intellectually, maybe even physically grasp that the person suffering was indirectly or directly talking to me and that I should have tried to do something about that suffering.

This is not an argument against the claim that novels influence our moral and political selves. I only refer to the gulf that lies between intellectually recognizing other people's lives and acting on that recognition by not privileging any form of living. As Jenefer Robinson convincingly argues, novels indeed affect our emotions directly and pre-cognitive, but the cognitive reflection on perception and attentiveness is a very complicated and only secondary task. She argues against the assumption that "emotions are or entail beliefs or judgments, and that this cognitive component is the most fundamental aspect of emotion. Moral learning through reading fiction does not consist of the acquisition of beliefs. Learning about life by reading fiction would then seem to consist of the acquisition of beliefs". This is too much of a mechanical model for her of what goes on in the emotional experience of novel-reading: "We will never be able to abstract a 'message' from a great novel by means of an after-the-fact summary of it” [18]. The emotional experience of reading a novel, she argues, is educational because emotions are tools for focusing our attention. True, by reading a novel I may acquire the belief that careful attention to and awareness of the details of a situation or person should be part of my own intellectual web of moral beliefs and habits. However, such reflective insights are the results of cognitive monitoring of the series of emotional experiences I have had over 
the course of reading the novel. I am reflecting back on these experiences. Thus, the education I receive in reading the novel is not just a matter of acquiring these beliefs (that I should be more attentive). This has to do with the polyphonic structure of good novels. They ask questions but do not answer them unambiguously. They leave room for readers to engage in reflections on their emotional experience and its ethical implications. Hence, cognitive reflection and interpretation on moral and ethical issues have to take into account the openness and complexity of novels as well as the varied and complex emotional experiences of the readers.

Rortyan literary intellectuals with their aloof interpretations may be of some assistance to some already well educated experts for cognitive reflection on reading-experiences. On the other hand, the vast majority of people are not such experts, real live teachers that help to transform the reader's emotional reading-experiences by enacting these transformations before their eyes into something like moral beliefs or habits are very important. They use novels as training tools for such transformations. A philosophy of democracy that puts its hopes on a culture that is first and foremost democratic because it is an artistic culture has to be connected with philosophical reflections on education. The right novels, in order to fulfill the functions of criticism and of making us into better perceivers, have to be read in the right environment, and that means that novels, as any form of art, have to be taught and imparted [19].

The most considerable writing of Rorty on philosophy and education is "Education as Socialization and Individualization" [20]. However, this article is not a reflection on the processes of education but an analysis of the landscape of educational politics in the US at the time. Distinguishing between "lower education" (primary and secondary education) and "higher education", Rorty sees the purpose of lower education in enculturation and socialization, "of getting the students to take over the moral and political common sense of the society as it is", whereas the purpose of higher education would be to educate us in freedom, individuation and criticism by "inciting doubt and stimulating imagination, thereby challenging the prevailing consensus” ([20], pp. 116, 118). As for Rorty "education for freedom cannot begin before some constraints have been imposed”, socialization has to come before individuation. It is not hard to see that arranging lower and higher education in that way is a direct result of Rorty's splitting-up of the private and the public realm (and is in accordance with the two functions he ascribes to novels). On exactly how we should envisage these concrete processes of lower and higher education Rorty does not say much, he instead refers to Dewey's theory of education that for him already outlined this task. However, this reference to Dewey seems to be nothing but some sort of lip service [21]. It is not only that Rorty did not have much to say about education and democracy, he was convinced that philosophy has nothing to say about education, as philosophy's function cannot be to formulate any sort of theory but rather should be seen in its therapeutic use [22].

Still, Rorty acknowledged that novels are not successful in enhancing our powers of moral perception when they are read as—what I call—allegories for a particular moral theory or ideology. What do I mean by 'allegories'? To attribute novels an allegoric function means to treat them as a lively example for a general idea or principle. To treat novels as training instruments for moral and political education on the other hand would attribute to them a much more instrumental function, instrumental insofar, as novels as training instruments amplify personal experiences and by that influence future personal action. Referring to Harold Bloom, Rorty "regards ideology—in the sense of a set of general ideas which provide a context in which the reader places every book she reads_as an 
enemy of autonomy" [23], and, one could add, as an enemy of reader sensibility. Rorty's account of novels as powerful tools for enhancing our moral imagination is thus opposed to the view that novels seek to enunciate general moral or ethical principles. Such principles are not in novels, and thus no general moral lessons should be extracted from the concrete situations portrayed in literature, in particular, from the rich, finely woven, detailed situations that characterize polyphonic novels. They are complex and ambiguous as they display simultaneously many voices that cannot be reduced to one moral generality. Suppressing complexity would mean the reduction of existence to thin, stereotypical caricatures and would in effect deny the resources - the ambiguity, paradox and complexity of existence-necessary for changing the conventions. Thus, novels that instruct us on how to live morally can be discerned from novels that do not instruct us on how to live morally but rather only implicitly ask questions on how we want to live at all.

Rorty's hope that getting inside the skin of others would induce us to break up fixed (moral) principles and worldviews is close to John Dewey's and Martha Nussbaum's concepts of literature and art as training instruments for educating our power of perception. For Nussbaum, for instance, the detailed attention we put into attending to a literary depiction is an instance of the attention needed in moral activity [24]. Similarly, for Dewey, perception is opposed to mere recognition. Recognition for him is mere stereotype information upon some previously formed scheme, whereas perception means to "take in", realizing that we never knew the object of perception before, that we had not seen it in any pregnant sense ([19], pp. 59-62). The function of art for Dewey is to focus on subdued parts of experience and in Deweyan terms, to create and provide access to aesthetic experiences. That means among other things the following, as Dewey declares in Art as Experience: "The moral function of art itself is to remove prejudice, do away with the scales that keep the eye from seeing, tear away the veils due to wont and custom, perfect the power to perceive” ([19], p. 328). In such a perspective, novels and art in general are training tools for making us into better perceivers.

Yet Rorty did (against what I outlined before) cherish the hope that such novels would teach us moral lessons. There is a tension between his hope that by reading polyphonic novels we come to see that any form of fixed morality stands in our way of really seeing what other people need and why they are suffering, and his hope that reading those novels would make us loyal to a real existing liberal democratic ethnos. Whenever Rorty considers political issues, the nation is the most relevant 'we'-identity for him when it comes to realizing the ideal of solidarity; and in his case the most relevant nation is the United States, which he takes to be a good example of a democratic society in "the West” [25], though he occasionally cannot decide whether he should criticize its realities or laud it as "a great country” [26]. Thus when Rorty appeals to the common identity of fellow Americans it is unclear if he has in mind the actual 'we' of identity or the America which it could be as measured by the ideals of his liberal democratic utopia. This tension refers to the before mentioned tension between the loyalty to a factual 'we'-identity (the United States) and a normative 'we' of a Sellersian 'we-consciousness' (the universal liberal utopian ideal of solidarity). When he states, however, that we should not be looking for alternative practices to real existing liberal democracies_- “we do not need ... 'a critique of liberal society'. We just need more liberal societies, and more liberal laws in force within each such society”- he clearly is taking sides on that matter [27].

In other words, Rorty's view about novels' potential for moral progress oscillates between the hope that novels would be efficient tools for subverting and destructing any form of a "morality" and the 
hope that they would be efficient propaganda tools for something like a 'liberal morality' that already exists in the US. However, that the latter hope undermines the task of subverting and destructing moralities is addressed by Dewey in Art as Experience: “The theories that attribute direct moral effect and intent to art, fail because they do not take account of the collective civilization that is the context in which works of art are produced and enjoyed". Such theories "tend to extract particular works ... form their milieu and to think of the moral function of art in terms of a strictly personal relation between the selected works and a particular individual. Their whole conception of morals is so individualistic that they miss a sense of the way in which art exercises its human function” ([19], pp. 348-49). What Dewey criticizes is that art is mainly seen as a function of a moral system already developed. For Dewey, it is the other way round: morality should be seen as a function of art. Art is moral by disclosure, "through imaginative vision, addressed to imaginative experience of possibilities that contrast with actual conditions". He holds: "A sense of possibilities that are unrealized and that might be realized are when they are put in contrast with actual conditions, the most penetrating "criticism" of the latter that can be made. It is by a sense of possibilities opening before us that we become aware of constrictions that hem us in and of burdens that oppress” ([19], p. 349).

\section{Novel's Political Function of Educating our Capacity for Criticism}

Orwell's 1984 is another story for Rorty where we could train to become more sensitive and more solidary, where we could learn that our attempts for self-realization might have consequences that will make other people suffer. Indeed, Orwell's 1984 may teach us that sheer brutality and the use of senseless violence intended to humiliate, de-humanize and de-individualize its opponents lead to cruel and inhuman consequences and therefore are bad. However, if ever we could draw normative conclusions from a book like 1984, it would be in my view political lessons about power. It would be the warning to be very vigilant that our political structures are organized in a way that they prevent us from a guy like O’Brien coming into power. I think that any kind of dystopia has its political function not because it makes readers more sensitive and more solidary, but rather because it is a form of social criticism.

Stories can have critical, subversive power for Rorty, but they have this power only for changing one's own personal vocabulary and not for social criticism. For Rorty, creating one's original vocabulary and producing unprecedented redescriptions are sources for self-criticism and autonomy. Yet how do redescriptions tap critical potential? They do that - to take up what was already mentioned in the above quotation by Dewey-by contrasting actual realities with depicted possibilities. In this contrast lies a critical perspective on actual realities and potential for change by assessing those realities with hindsight from the vision of a different future. Of course, Orwell's 1984 is a dystopian imagination, and in effect a prolongation and enlargement of actual realities, a narrative of how it might turn out in the West. The problem with Rorty's account might be that 'actual realities' have an uncertain place in it. Orwell's scenario in 1984 is to be compared, by Rorty's own account, not with reality but with other alternate scenarios, with other novels. Yet the crucial point of 1984 is that its setting did resemble the totalitarian society of the Real Existing Socialism of Orwell's time and the wartime life in Great Britain that had the tendency to implement totalitarian instruments like surveillance, censorship, sexual repression, nationalism, rigorously enforced class distinctions, cult of 
personality, and so on. Indeed, Orwell did acknowledge that his writing since 1939 was "written, directly or indirectly, against totalitarianism and for democratic socialism” [28]. As Rorty's antirepresentationalism rejects any form of correspondence theory, it is not possible for him that imaginative novels could be compared with actual reality, and thus much of the potential critical force that redescriptions could offer, is thrown away.

However, Rorty could hold that he can integrate the comparing-function necessary for social criticism into his account. He could argue that fictional novels actually might refer to existing realities. Nonetheless, such realities would be nothing outside of novels but exactly and exclusively the novels themselves. In other words, in Rorty's account, the comparing-function is not between novels and realities but between one specific narrative and alternative ones. If we understood social criticism as an inner-narrative comparing-function, social criticism, in order to actually criticize, would have to conceive the comparing-function within a discourse between competing novels. Yet is it not a strange way of speaking to say that fictional novels, insofar as they fulfill the function of social criticism, do not contrast with real or realistically possible totalitarian patterns, say censorship, but only with other novels or a discourse? The problem with that view seems to be that we could only contrast those social realities that already are present in a story. However, changing stories is not what we want exclusively, we rather want to change social realities.

Rorty could reply that by changing vocabularies, we are changing realities too, or that at least we are changing the condition of possibility of realities. Yet this is only half the story. Changes in vocabulary are often only indications of actual social changes that take place somewhat 'outside' of novels. However, if we consider Dennetts report that Rorty conceded to him in private that it is indeed important to acknowledge the gap between appearance and reality when we, e.g., want to compare two maps of the countryside for reliability for example, or when we want to find out whether the accused did or did not commit the crime as charged. As Dennett reports, Rorty in that context spoke of “vegetarian” concepts of truth and reality [29]. With this in mind I should soften my criticism of Rorty on that matter but still reproach him for going too far in his writings with his polemic against models of epistemology that build their conclusions on the premise that our concepts in one way or another mirror realities. Because he strictly rejects any such epistemology, he has no place for the correspondence function between concepts and realities and by that weakens the novel's power for social and political criticism.

\section{Conclusions}

Making us into better perceivers and providing us with the material to criticize our own personal vocabulary (and I add: social realities) are two separated functions of novels for Rorty. I now turn to why I think that these two functions are closer to each other than Rorty thinks they are, especially when one allows criticism to be more than just a tool for becoming more individual and autonomous.

Dewey, one of Rorty's heroes, did see that the power of perception is a prerequisite for criticism and that the power of moral perception has many internal similarities with criticism as a form of action. For Dewey, critical action should be carried out with the ideal aim of fostering experiences that liberate new meanings and values and help us to look at other people and the world in a different way. This is to say that criticism for Dewey should be "artful criticism", to use a term of Scott Stroud [30]. 
For Dewey, criticism is a form of action that can be executed artfully or non-artfully. If it is executed artfully, criticism should not be mechanical, but rather an attentive endeavor with openness to the present situation. For the artful critic, each claim is merely a way of using the present experience in a certain way. The art lies in how one focuses one's attention on that present usage. The Deweyan notion of artful criticism is, evidentially, closely connected to his concept of aesthetical experience. Dewey's ideal of aesthetic experience is a way of perceiving, a way of seeing the present situation as integrally connected to remote states as well as a way of valuing the present situation as much more than remote states, future goals, past events, and so forth.

With Dewey, we could say that before there can be deliberative criticism, there must be a capacity to hear each other's stories and experience the world relating to the other's mind and body. Becoming open at least to the possibility of other people's experiences or their way of meaning making is to develop an "epistemology of the ear" (Thomas Alexander) [31]. If criticism leads to actual changes, a disposition for listening to other people's voices - that is receptivity combined with imagination-is necessary. Thus, criticism has a precondition that Dewey saw and that Rorty did not see, namely that we need to learn to listen and to watch. Art (and that of course can include novels and stories) can help us train such qualitative perception, and then criticism can be effective.

The value of art's critical potential for Dewey is not just that it urges people to take the effort to become more individual and more autonomous through a very private process of re-creating their selves by criticizing their own vocabulary. In addition to that it is that it helps to educate our will to reflectively recognize or maybe even understand and integrate into our lives the meanings and practices that lie idle in our experiences of social realities. In short, the transformative capacity of art in Dewey's account of the moral function of art is art's ability to put us in touch with a pre-discursive mode of experience by cultivating our receptivity to the pervasive qualitative dimension of our fundamental transactions in the social and political environment. Critical judgment and aesthetic-moral perception here are closely related. An ethics of perception already implies the claim to challenge and criticize our established concepts and modes of individual and social lives. And criticism, in order to be social, implies the readiness to be attentive to social realities, to actual conditions of other persons, of social structures and patterns, of processes and institutions.

An important aspect of Deweyan artful criticism is that it is not what elitist critics do, it is what everyone does in certain problematic situations, namely investigating the present in light of what is not present, it occurs when we pass from appreciation to engaged reflection. In Experience and Nature, Dewey expresses this idea like this: "Criticism is not a matter of formal treatises, published articles, or taking up important matters for consideration in a serious way. It occurs whenever a moment is devoted to looking to see what sort of value is present; whenever instead of accepting a value-object wholeheartedly, being rapt by it, we raise even a shadow of a question about its worth, or modify our sense of it by even a passing estimate of its probable future" [32]. Criticism is an activity that all can and should take part in, whether in relation to our experience of traditional art objects in a museum, of political speeches or in relation to aspects of our everyday life that can be improved. Thus, for Dewey, art is a necessary constituent of democratic societies and not just its smooth, shiny ornamental surface. If art is understood as an instrument for political expression, as Mark Mattern highlighted, it "is a source of power for many. This is especially true for relatively marginalized individuals and groups who frequently find themselves locked out of mainstream and institutionalized political 
arenas” [33]. In that sense, art is and can be understood as a means of stimulating public debate and political deliberation.

John Dryzek said that pragmatism's most important contribution to the philosophical discussion about democracy is that it emphasizes that "deliberation in practice is often more about telling stories than it is about making arguments" [34]. He mainly refers to Rorty's narrative account, which in Dryzek's eyes is much better suited to represent political deliberation in deeply pluralistic democratic societies than models of deliberative democracy. These are essentially centered around the regulative ideals of consensus and truth-tracking, because it emphasizes the characteristic of political deliberation to be about diverse opinions that are presented in a narrative structure. One had not to go so far as to tax a political 'argument' - being rhetorically and aesthetically structured and thus selective and shaped for certain specific political purposes-as "an attempt to lie by speaking the truth" (Schumpeter) [35]. That would be to deny any value of political deliberation. Sure enough, the idea that art in general and narratives in particular can positively influence political debate is a highly normative ideal, because it for one thing presupposes that people bring along the intellectual capacity and curiosity to engage with art that challenges (or confirms) their volitions and for the other it demands that we can discern art and narratives which in principle have the potential to influence from artworks that do not have this potential. That the latter is not only a matter of artworks' structures or of the aesthetical or moral attributes they imply but also a matter of their reception, of how artworks and stories are conveyed. Without going into detail about this question here, in the light of what has just been said about dispositions for democratic citizenship, both artworks and their reception should in some way or another, directly or indirectly, touch upon and shed light on aspects of social or existential-individual realities and experiences that so far have been largely unveiled. By doing that, they can add an aesthetically- or a linguistically-constituted variety of opinions or 'arguments' to the public discourse.

However, given the coherences between the capacities of criticism and aesthetic-moral perception it should not be forgotten that many valuable artistic contributions to political deliberation serve as means for resistant and oppositional political practices. Both Dewey and Rorty neglect to acknowledge the positive effects of conflict, disruption, competition and disharmony in democratic politics. In fact, art and artistic criticism—by directly provoking, antagonizing or mocking political opponents_are significantly successful in bringing disregarded voices into political deliberation by advancing the political concerns of a certain social group, spreading such concerns or motivating citizens to participate in political debate and vote. Only consider the latest example: Pussy Riot; or think about the series “Top Goon” of the Syrian artist group “Masasit Mati”. There is empirical evidence that public irony and ridicule are twice as successful as strategies for overcoming oppressing or illegitimate political regimes as revolution by force [36]. What Dewey neglects and Rorty considers but unfortunately limits to the private sphere is that antagonism and disruption in art and artistic criticism can be a valuable means for public debate.

\section{Acknowledgments}

My thanks go to Michael Festl, Ralph Weber, Anita Horn, and the anonymous reviewers for their comments. 


\section{Conflict of Interest}

The author declares no conflict of interest.

\section{References and Notes}

1. Richard Rorty. Essays on Heidegger and Others, Volume 2: Philosophical Papers. New York: Cambridge University Press, 1991, 68.

2. Richard Rorty. Philosophy and Social Hope. London: Penguin, 1999, 74.

3. Daniel C. Dennett. "The Self as a Center of Narrative Gravity.” In Self and Consciousness: Multiple Perspectives. Edited by Frank S. Kessel, Pamela M. Cole, and Dale L. Johnson. New Jersey: Lawrence Erlbaum Associates, 1992, 103-15.

4. Gottlob Frege. The Foundations of Arithmetic: A Logico-Mathematical Enquiry into the Concept of Number. Evanston: Northwestern University Press, 1980, VII.

5. Richard Rorty. "Response to Bjorn Ramberg.” In Rorty and His Critics. Edited by Robert Brandom. Oxford: Blackwell, 2000, 376.

6. Richard Bernstein. “Richard Rorty’s Deep Humanism.” New Literary History 39 (2008): 13-27.

7. Richard Rorty. Contingency, Irony, and Solidarity. Cambridge: Cambridge University Press, 1989, 73.

8. Michael Bacon. “A Defense of Liberal Ironism.” Res Publica 11 (2005): 407-08.

9. Richard Rorty. Take Care of Freedom And Truth Will Take Care of Itself: Interviews With Richard Rorty. Edited by Eduardo Mendieta. Stanford: Stanford University Press, 2006, 80-81.

10. See Neil Gascoigne's elucidating discussion of the difference between intellectual ironists and non-intellectual historicist-nominalist citizens. Neil Gascoigne. Richard Rorty. Cambridge: Polity Press, 2008, 175-82.

11. Michael Brint, William G. Weaver, and Meredith Garmon. "What Difference Does AntiFoundationalism Make to Political Theory?” New Literary History 26 (1995): 226.

12. John Dewey. The Public \& Its Problems. Athens, OH: Swallow Press, 1954, 148.

13. Jürgen Habermas. Between Facts and Norms: Contributions to a Discourse Theory of Law and Democracy. Cambridge, MA: MIT Press, 1996, 317.

14. Christopher J. Voparil. Richard Rorty: Politics and Vision. Lanham: Rowman \& Littlefield Publishers, 2006, 61-88.

15. Milan Kundera. The Art of the Novel. New York: Perennial, 2000, 164.

16. Richard E. Hart. "Richard Rorty on Literature and Moral Progress.” Pragmatism Today 2 (2000): 40.

17. Vladimir Nabokov. The Annotated Lolita. Edited by Alfred Appel. New York: McGraw-Hill, 1970, 215.

18. Jenefer Robinson. Deeper Than Reason: Emotion and Its Role in Literature, Music, and Art. New York: Oxford University Press, 2005, 155-56.

19. John Dewey. The Later Works 10, 1925-1953. Carbondale and Edwardsville: Southern Illinois University Press, 1985, 361. 
20. Richard Rorty. "Education as Socialization and Individualization." In Philosophy and Social Hope. London: Penguin, 1999. Originally published under the title "Education without Dogma." Dialogue 2 (1990): 44-47.

21. Kenneth Wain. "Richard Rorty, Education, and Politics." Educational Theory 45 (1995): 395-409.

22. Richard Rorty. "The Dangers of Over-Philosophication-Reply to Arcilla and Nicholson." Educational Theory 40 (1990): 41.

23. Richard Rorty. "Redemption from Egotism: James and Proust as Spiritual Exercises." In The Rorty Reader. Edited by Christopher J. Voparil and Richard Bernstein. West Sussex: Wiley-Blackwell, 2010, 390.

24. Martha C. Nussbaum. Love's Knowledge: Essays on Philosophy and Literature. New York: Oxford University Press, 1992, 148.

25. Richard Rorty. “Response to Thomas Schäfer.” In Hinter Den Spiegeln: Beiträge Zur Philosophie Richard Rortys. Edited by Thomas Schäfer, Udo Tietz and Rüdiger Zill. Frankfurt am Main: Suhrkamp, 2001, 198.

26. Richard Rorty. "The Demonization of Multiculturalism.” Journal of Blacks in Higher Education (1995): 74.

27. Richard Rorty. "Response to Simon Critchley." In Deconstruction and Pragmatism. Edited by Chantal Mouffe. London: Routledge, 1996, 45.

28. George Orwell. Why I Write. New York: Penguin, 2005, 8.

29. Daniel C. Dennett. "Postmodernism and Truth." The Proceedings of the Twentieth World Congress of Philosophy 8 (2000): 93-103.

30. Scott R. Stroud. “John Dewey and the Question of Artful Criticism.” Philosophy and Rhetoric 44 (2011): 27-51.

31. Thomas M. Alexander. “The Art of Life: Dewey's Aesthetics.” In Reading DeweyInterpretations for a Postmodern Generation. Edited by Larry Hickman. Bloomington and Indianapolis: Indiana University Press, 1998, 18.

32. John Dewey. The Later Works 1, 1925-1953. Carbondale and Edwardsville: Southern Illinois University Press, 1985, 299.

33. Mark Mattern. “John Dewey, Art and Public Life.” The Journal of Politics 61 (1999): 72.

34. John S. Dryzek. "Pragmatism and Democracy: In Search of Deliberative Publics.” The Journal of Speculative Philosophy 18 (2004): 74.

35. Joseph A. Schumpeter. Capitalism, Socialism and Democracy. London: Routledge, 2000, 264n18.

36. Erica Chenoweth, and Maria Stephan. Why Civil Resistance Works: The Strategic Logic of Nonviolent Conflict. New York: Columbia University Press, 2011.

(C) 2013 by the author; licensee MDPI, Basel, Switzerland. This article is an open access article distributed under the terms and conditions of the Creative Commons Attribution license (http://creativecommons.org/licenses/by/3.0/). 